\title{
Filosofia e arte como resistência
}

\author{
João Virgílio Tagliavini (1) \\ Departamento de Educação \\ Universidade Federal de São Carlos
}

Quando comecei a pensar neste tema, veio-me em primeiro lugar uma pergunta sobre o sentido de "resistência". Resistência não é um termo unívoco. Segundo o vocabulário técnico e crítico da Filosofia de LALANDE (1996: 958), resistir é "fazer obstáculo, opôr-se a um movimento, no sentido próprio ou no figurado... defender-se ... não ser destruído ou decomposto por uma ação exterior". Neste sentido, pode ser a resistência francesa contra a ocupação nazista, como pode ser a resistência católica da contra-reforma que mais tarde se traduz numa postura contrária à própria modernidade. Pode ser a resistência à vida e aos prazeres, praticada por anacoretas, ermitões e todos os estóicos, ou a recusa da penitência $e$ do sofrimento, própria dos hedonistas. Quem ama a vida, peita a morte e resiste contra ela, em vão, é claro, mas resiste. Quando não tem mais jeito, continua resistindo, desfraldando a bandeira da crença na eternidade. A resistência parece fazer parte da busca desesperada por um sentido para a vida.

Na mitologia grega há dois exemplos clássicos de resistência, nas primeiras obras de arte do ocidente: Hércules e Ulisses (Odisseu) são personagens típicos que resistem às provações que lhes são impostas pelos deuses. A resistência em aceitar o seu destino faz os gregos criarem o mito de Prometeu que, vendo os homens indefesos, roubou a sabedoria técnica de Hefesto e de Atenas, juntamente com o fogo, distribuindo-os aos mortais.

As artes da Antigüidade que resistiram ao tempo, embora muitas vezes mutiladas, são testemunhos vivos de uma época: o Partenon, na acrópole de Atenas, santuário dedicado à deusa da sabedoria; o teatro de Epidauro, construído por volta de 330 a.C., palco dedicado aos trágicos gregos; a "basílica" de Pesto, na Magna Grécia, que data de 540 a 530 a.C., primeiro templo dedicado a Hera; o Coliseu, do século I da era cristã, a Vênus de Milo, escultura do ano 100 a.C., que hoje é uma das peças mais preciosas do museu do Louvre; poderíamos passar pelas Catedrais erguidas na Idade Média e pelas obras do Renascimento, como a Mona Lisa de Da Vinci e o Davi de Michelangelo.

Arte e Filosofia são uma resistência ao que é aparente no mundo sensível, na busca de um outro sentido. Platão, que nutria certa aversão pelas artes, pois elas seriam "imitação da imitação" das sombras que constituem o mundo sensível, buscou a superação das aparências no "mundo das idéias", onde estão as verdadeiras essências, ou o sentido último das coisas. $\mathrm{O}$ mito da caverna e a teoria da reminiscência demonstram a resistência de Platão em aceitar o "senso comum", do mundo das sombras da caverna. 
Na história da filosofia, podemos dizer que Sócrates, ao ser acusado de corromper a juventude e desprezar os deuses de Atenas, resistiu até o fim, preferindo o próprio sacrifício, bebendo a cicuta que lhe fora imposta pelo tribunal, do que ter que se retratar. Diógenes de Sinope, maior representante dos cínicos, que pregava e vivia o desprezo pelos prazeres, é o símbolo da filosofia capaz de resistir aos encantos do mundo: quando se vê frente à frente com Alexandre Magno que lhe insistia para que fizesse qualquer pedido, Diógenes pede apenas que não lhe seja retirado o sol, pois só disso ele precisava para viver. O resto não despertava interesse.

Numa perspectiva weberiana, a resistência à ordem estabelecida, num primeiro momento, pode tornar-se "instituição", num segundo momento. O cristianismo primitivo foi, no início uma resistência à ordem estabelecida dos sacerdotes do Templo de Jerusalém e às cruéis perseguições do Império Romano que acabavam muitas vezes num ritual de martírio, no Coliseu, quando cristãos eram entregues às feras. Séculos depois, o Coliseu tornou-se lugar sagrado, onde os cristãos veneravam seus mártires, onde o papa reza, todos os anos, na Sexta-Feira Santa, a via crucis de Cristo.

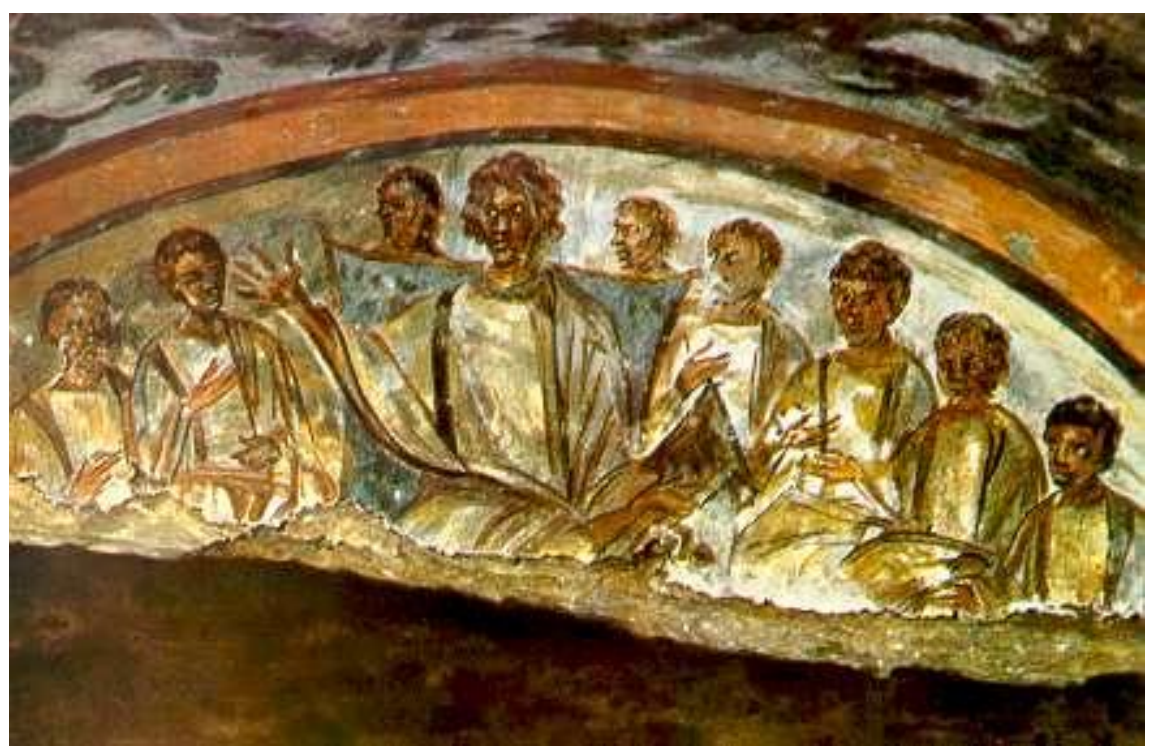

Cristo e os apóstolos, nas catacumbas Santa Domitilla, em Roma 




Os corredores da Catacumba Santa Domitilla

Nessa mesma Roma, as primeiras artes dos cristãos estavam nas paredes das catacumbas (2), sepultura dos mártires, onde artistas representavam cenas e símbolos do cristianismo. Com a liberdade religiosa concedida por Constantino, pelo edito de Milão, em 313, e depois da declaração do cristianismo como religião oficial do Império, por Teodósio, em 380, os cristãos saem das catacumbas e vão para os palácios e não demoram a construir as catedrais, suas grandes obras de arte, cujas esculturas e cenas retratadas nos vitrais constituem o primeiro catecismo para um povo ignorante e analfabeto. O Cristo do sofrimento e da paixão, dos primeiros tempos, transformar-se-á no Cristo Pantocrátor (todo-poderoso), tão caro aos cristãos orientais. É um Cristo coroado de luzes, rodeado pelos evangelistas e pelos anjos, um Cristo glorioso. Voltará a ser, no século XIII, no apogeu do estilo gótico, um Cristo mais humano, paciente, com coroa de espinhos, preso a um crucifixo pelas mãos e pelos pés, tendo seu lado perfurado pela lança.

O mausoléu de Diocleciano, responsável por uma das mais terríveis perseguições aos cristãos, tornou-se santuário cristão. Na audiência de 07 de Outubro de 1998, João Paulo II, recordando sua recente viagem à Croácia, disse:

A actual cidade de Espálato, que inclui a antiga sede episcopal de Salona, contém no centro o Palácio e o Mausoléu do imperador Diocleciano, que foi um dos mais cruéis perseguidores dos cristãos. E eis que, alguns séculos depois, o Mausoléu foi transformado em Catedral e entre as suas paredes foram postas as relíquias de São Domnio, Bispo de Salona e mártir.

O Panteón romano era um tempo dedicado a todos os deuses; hoje é igreja cristã. O mosteiro de Monte Cassino, na Itália, foi fundado sobre as ruínas do Templo de Júpiter.

Os padres, doutores da igreja, como Agostinho, que elaboraram uma filosofia e uma teologia de resistência às coisas do mundo, para a construção da "cidade de Deus", foram sucedidos por uma escolástica que tenta integrar a filosofia de 
Aristóteles e a teologia, buscando uma forma de justificar a presença e atuação da igreja no mundo da Idade Média.

A Reforma Protestante pode ser vista como resistência à situação de decadência da igreja católica. Bispos e padres que não moravam em suas dioceses e paróquias, vida desregrada do clero, ambição pelos bens terrenos, intrigas políticas etc. A igreja católica posicionou-se, com a Contra-Reforma, orquestrada a partir do Concílio de Trento, na segunda metade do século XVI. O auge da resistência à modernidade, na filosofia cristã, toma corpo na Encíclica Quanta cura, completada pelo Syllabus, ou Índice dos principais erros do século XIX, promulgada para toda a Igreja pelo Papa Pio IX, em 08 de Dezembro de 1864. Logo depois, o mesmo papa convoca o Concílio Vaticano I, que declara a infalibilidade do papa em matéria de fé e moral.

Apesar de toda resistência, modernidade tomou seu caminho sem volta, com auxílio, além da reforma protestante, da invenção de imprensa, das grandes navegações e "descobertas" de novos mundos, o desenvolvimento da ciência, com Galileu, Newton e com os iluministas que vieram a seguir.

Voltaire, Rousseau e tantos outros defenderão uma antropologia contrária à cristã tradicional: o homem era bom em si mesmo, não tinha sido corrompido pelo pecado, não tinha necessidade de uma redenção que descesse do alto para salválo. Era capaz de conquistar sua felicidade, descobrir a verdade e fazer o bem com suas próprias forças. A razão, sempre igual em todos os tempos e em todos os povos, constituía-se na via e na norma única e absoluta da verdade (3).

É a filosofia que resiste à explicação estabelecida. Em Paris, o Panteón é transformado em Templo da Razão.

O começo do filosofar é sempre uma inquietação que não deixa aceitar a primeira explicação dada da realidade. Por exemplo: por que as coisas acontecem? Qual é a causa dos acontecimentos? É o acaso, o fortuito, o fado, o destino, um movimento de atração, vontade dos deuses, providência divina que respeita o livre arbítrio do homem, mecanicismo, necessidade, o modo de produção...? Tantas perguntas que envolveram as respostas do epicurismo, estoicismo, aristotelismo, mitologias, religião, marxismo etc. Há sempre uma resistência em aceitar a primeira e única resposta. Para os primeiros filósofos gregos, os homens começaram a filosofar por causa da admiração, do espanto. Admiração e espanto provocados em nós pelas obras de arte que resistem ao tempo e se tornam universais. Aceito aqui o desafio de mostrar duas dessas obras.

\section{DE GOYA A PICASSO}

Dois artistas, duas obras, um tema: a resistência espanhola e o sofrimento de um povo. "O três de maio de 1808" pintado por Goya, em 1814, e "Guernica", de Picasso, pintado em 1937. São obras que, segundo LICHT (2001, p. 165) "ultrapassam a estética, a arte e a história da arte e se convertem em imagens arquetípicas que condicionam o curso da existência." 
Francesco Goya (4) retrata os horrores de uma guerra que se iniciou em 1808 e só terminou em 1814. Era a ocupação napoleônica, que se iniciara há um ano e a resistência espanhola, tradicional e fiel ao seu monarca e à igreja. Goya tinha sido simpático à ocupação francesa, pois acreditava na necessidade de uma "iluminação da Espanha pela Razão", obra que poderia ser realizada com a ajuda externa, por aqueles que já tinham feito sua revolução. Para ele, o "sono da razão cria monstros". A Espanha apegada ao seu rei e à igreja, representava tudo o que fora contestado pela revolução da "liberdade, igualdade e fraternidade". Há uma luta de ideais filosóficos entre o espírito da Ilustração e as forças retrógradas que dominavam muitos países da Europa. Simpático à ocupação, Goya tinha produzido obras que retratavam numerosos invasores, fizera juramento de "amor $e$ fidelidade" a José Bonaparte, mas não ficara insensível, por outro lado, aos sofrimentos do povo, pintando também, a partir de 1810, os "desastres da guerra". Em 1814, por ocasião da restauração da monarquia absoluta, sob Fernando VII, Goya, a pedido da corte retrata os horrores de 3 de maio.

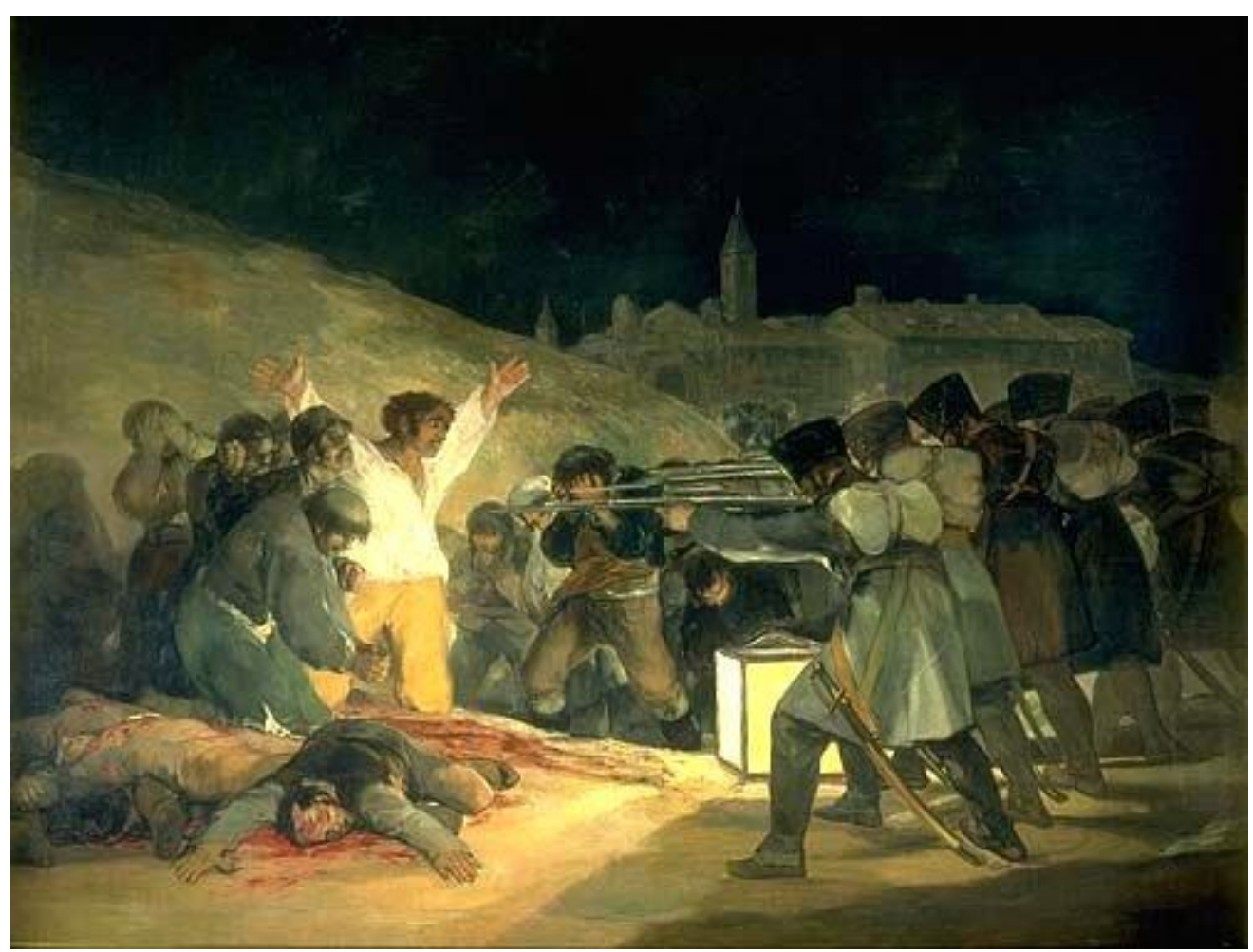

Três de Maio, Goya, 1814

Impossível ficar indiferente diante do quadro. Ele questiona a vida, a morte, a resistência e o poder. $\mathrm{O}$ quadro recorda o fuzilamento de uma multidão de espanhóis, cerca de 400 pessoas, na madrugada de 03 de maio, após o levante rebelde de 2 de maio, que tinha sido um símbolo de heroísmo e de luta pela liberdade. A cena se compõe de um condenado, de braços erguidos, suplicando a clemência que não virá, seguido de uma multidão que se perde ao fundo. Ele traja uma calça amarela e uma blusa branca, cores da representação oficial da Igreja Católica. Nas suas mãos, as marcas, como os estigmas de Cristo. Aparece também no primeiro plano um monge, representando a igreja, perseguida pela ocupação. $A$ igreja estava acostumada a se interessar por assuntos além da sacristia. A mesma 
igreja que lutara para expulsar os árabes, agora estava pronta para lutar pela expulsão dos novos ateus e infiéis, e Napoleão, o anticristo. Isso explica porque os espanhóis lutavam "por Deus, pela pátria e pelo rei".

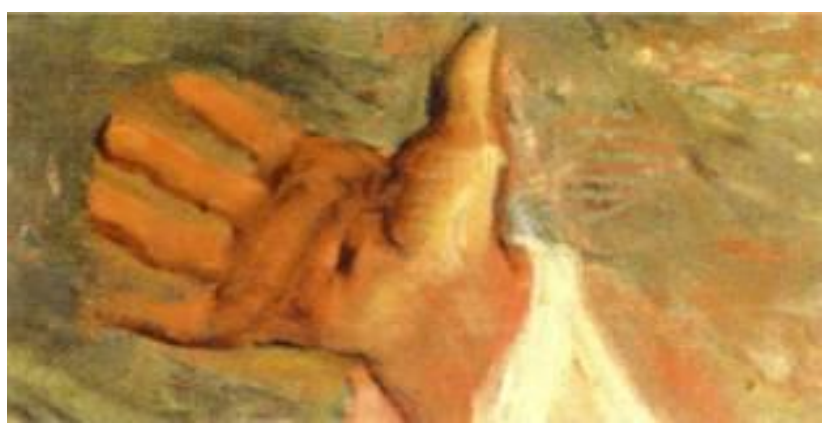

Detalhe de "Três de Maio", de Goya

Os personagens estão diante de um pelotão francês que já fuzilara dois espanhóis. A cena principal é iluminada por um farol. Não é a luz divina nem a luz da razão. É apenas a luz que rompe as trevas da madrugada para iluminar a tarefa executada pelo pelotão de fuzilamento. Não se trata do martírio de alguém muito conhecido, mas simplesmente de personagens anônimos. Tanto os soldados franceses, que estão de costas, quanto à massa, todos estão despojados de sua individualidade. "O três de maio de 1808 é o primeiro altar dedicado a milhóes de pessoas anônimas, cuja morte tem se convertido inexplicavelmente num assunto insignificante. O anonimato é a condição do homem atual... A morte deixou de ser um incidente individual, contemplado e julgado por um Deus que vê todas as coisas e se converteu, por sua vez, numa interrupção impessoal da vida, desprovida de um significado especial. Morrer tem tão pouco sentido quanto matar" (LICHT, 2001, p. 170). O quadro de Goya não permite a observação objetiva; seu significado salta da tela e questiona a todo aquele que o contempla. Não há indiferença diante dessa obra prima do autor de muitos quadros que versam sobre os horrores da guerra. A trágica imbecilidade humana desfila sob os olhares dos observadores.

Há um enorme potencial pedagógico nessa obra da arte universal, que resiste ao tempo e nos permite uma ligação com outra obra espanhola, 130 anos depois: Guernica, de Pablo Picasso (5).

Em 26 de abril de 1937, com o auxílio da aviação nazista, o General Franco, que comandava a revolta do exército contra a II República Espanhola (6), mandou bombardear a cidade basca de Guernica. Numa cidade de aproximadamente sete mil habitantes, foram mortos 1654 e mais 889 feridos.

Em 4 de maio de 1939 o Prefeito de Guernica, dirigindo-se ao povo espanhol, divulgou o seguinte comunicado:

Em pé, diante desde microfone, quero contar o que os meus olhos viram no lugar do que já foi Guernica, e tomo Deus como testemunha: envergonhados pelo monstruoso crime que cometeram, os rebeldes apelam para a falsidade para camuflar, para negar a mais vil das proezas da História, a total e absoluta 
destruição da cidade de Guernica. Aquele dia fatal, 26 de abril, era dia de mercado e a cidade estava cheia de gente. Em Guernica havia milhares de camponeses de toda a vizinhança, numa atmosfera de camaradagem basca, e ninguém suspeitava de que uma tragédia se aproximava. Pouco depois das quatro da tarde, aviões jogaram nove bombas no centro da cidade. Procurávamos os feridos, quando mais aviões surgiram, jogando todo tipo de bombas, incendiárias e explosivas. As feras que pilotavam tais aviões, logo que avistavam nas ruas ou fora da cidade uma figura humana, focalizavam nela suas metralhadoras, semeando terror e morte, entre mulheres, crianças e velhos. Tal foi a tragédia de Guernica, cuja verdade, eu, prefeito da cidade, afirmo diante do mundo inteiro. A Milícia estacionada em Guernica, naquele dia, era exatamente a mesma que havia confraternizado todos esses meses com o povo de Guernica, ganhando sua afeição. Foi a primeira a prestar auxílio naqueles momentos terríveis. Não foi nossa milícia que ateou fogo a Guernica, e se o juramento de um alcaide cristão e basco tem algum valor, juro diante de Deus e da História que aviões alemães bombardearam cruelmente nossa cidade até riscá-la do mapa. Guernica foi ferida, mas não morrerá. Da árvore brotarão novas folhas verdes em toda primavera; seus filhos a ela retornarão; suas casas serão reconstruídas, suas igrejas escutarão novamente seus hinos e preces... Guernica, o símbolo de nossas liberdades nacionais, e o símbolo da ferocidade do fascismo internacional, não pode morrer."(7)

Picasso tinha sido convidado pelo governo oficial, republicano da Espanha para pintar um quadro monumental que deveria decorar o pavilhão nacional na Exposição Mundial de Paris, em 1937. Ele pensava em fazer o "Pintor e Atelier", mas, surpreendido pela covarde destruição de Guernica, cria, em maio/junho de 1937, a obra de arte, óleo sobre tela de 3,50 m. por 7,76m., com o título da cidade destruída. A destruição de Guernica, que poderia ter ficado no rodapé da história de mais um episódio de tantas guerras, foi colocada no centro do palco do século $\mathrm{XX}$, como um sinal da resistência à irracionalidade. Depois da exposição, o quadro não voltou para a Espanha, pois Picasso não queria que para lá voltasse até que Franco estivesse fora do poder. O quadro ficou num exílio de mais de 40 anos em New York, voltando para Madri, Museu do Prado, em 1981.

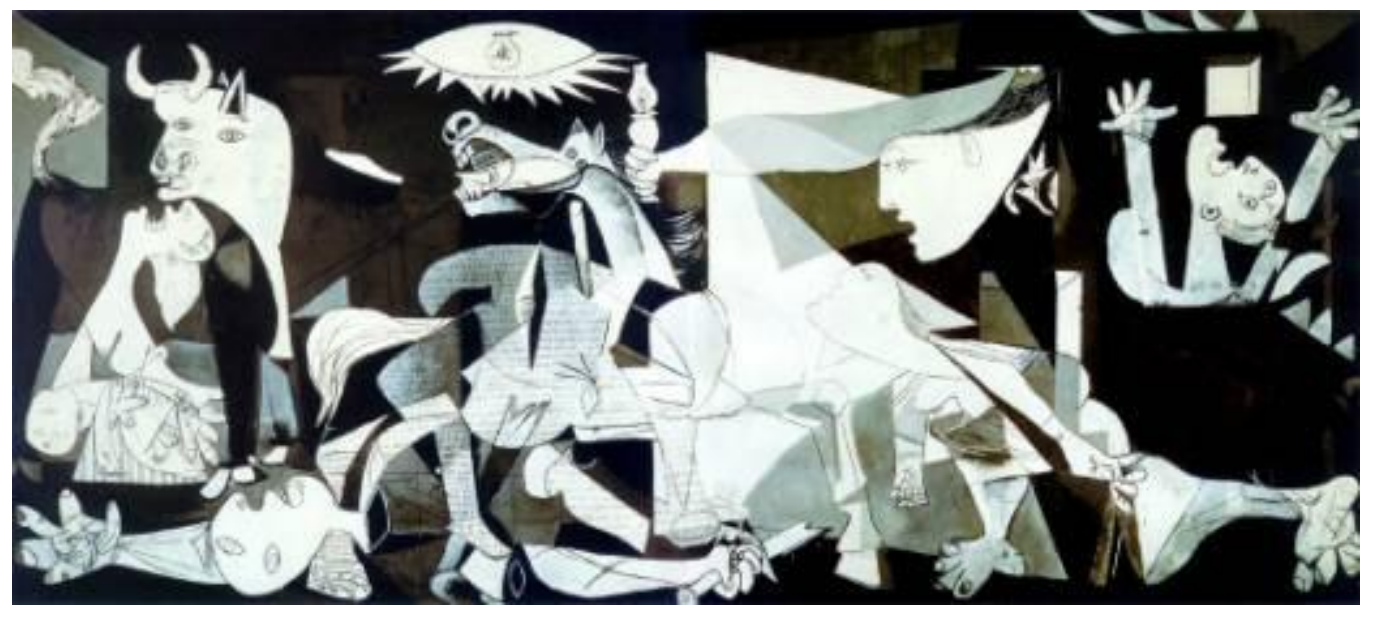

Na lateral direita superior do quadro há uma figura de homem de boca aberta e braços levantados, como o personagem central do quadro de Goya. Talvez ele 
esteja olhando para o céu, sem compreender as bombas que caem, suplicando, tentando segurá-las. Na lateral direita inferior do quadro há uma figura de mulher, como se carregasse um grande fardo nas costas, o que poderia ser o símbolo da cruz de Cristo. Exprime o sofrimento humano. À esquerda do homem de braços erguidos, há uma figura que surge de cima, de boca aberta, sem compreender o sofrimento que está ocorrendo. Na parte superior da tela há uma mão que segura uma lamparina, talvez a luz da consciência e da esperança. Próxima a ela está uma luz elétrica, no formato de olho, que talvez pudesse ser o olho de Deus que tudo vê. Abaixo da luz há um cavalo em agonia, certamente simbolizando o povo que sofre. Há também o touro, que seria símbolo do povo espanhol, tão amante de touradas ou seria o General Franco? Picasso não esclarece. Ele diz: "Este touro é um touro, este cavalo um cavalo (...). É preciso que o público, os espectadores, vejam no cavalo, no touro, símbolos que eles devem interpretar como os compreendem". A mais expressiva figura é a da mãe que, gritando de dor, carrega o filho morto nos braços. É a dor universal de todas as mães. Abaixo dela há um soldado caído, que segura na mão uma espada quebrada e uma flor. A flor é símbolo da esperança e a espada, símbolo da resistência. Ele parece dizer que enquanto houver resistência haverá esperança.

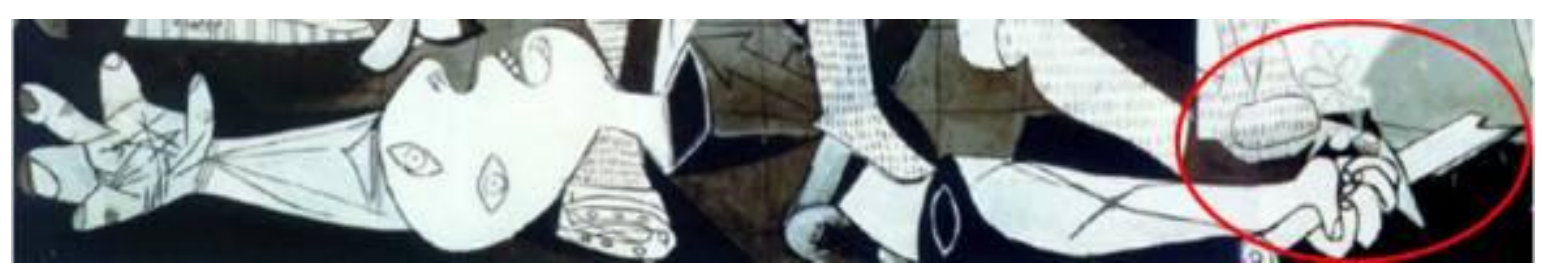

Guernica é obra de arte, é obra de filosofia. Existe na obra uma eternidade intemporal do sofrimento humano. $\mathrm{O}$ quadro descreve menos um fato histórico do que o efeito deste acontecimento sobre o espírito de Picasso.

Gritos das crianças, gritos das mulheres, gritos dos pássaros, gritos das flores, gritos das árvores e das pedras, gritos dos tijolos, dos móveis, das camas, das cadeiras, dos cortinados, das panelas, dos gatos e do papel, gritos dos cheiros, que se propagam uns após outros, gritos do fumo, que pica nos ombros, gritos, que cozem na grande caldeira, e da chuva de pássaros que inundam o mar (8).

Com essas palavras, Picasso termina o poema Sonho e mentira de Franco, no qual ele se refere pela primeira vez à guerra civil. Picasso pensa que a obra de arte é uma obra de resistência a algo que não se aceita:

O que pensa que é um artista? Um idiota, que só tem olhos, quando pintor, só ouvidos, quando músico, ou apenas uma lira para todos os estados de alma, quando poeta, ou só músculos, quando lavrador? Pelo contrário! Ele é simultaneamente um ente político que vive constantemente com a consciência dos acontecimentos mundiais destruidores, ardentes ou alegres e que se forma completamente segundo a imagem destes. Como seria possível não ter interesse pelos outros homens e afastar-se numa indiferença de marfim de uma vida que se nos apresenta tão rica? Não, a pintura não foi inventada para decorar casas. Ela é uma arma de ataque e defesa contra o inimigo.(9) 
O "Três de Maio" de Goya e o "Guernica" de Picasso são obras que ultrapassam o tempo e as fronteiras para fazer o homem pensar sobre sua vida, seu destino, a morte, a ambição, o poder e... a possibilidade de resistência.

A arte tem um enorme potencial pedagógico para a filosofia. Arte e filosofia, aliadas, servem de alavancas para a resistência.

\section{Bibliografia}

DUÉ, Andrea. Atlas histórico do cristianismo. Trad. Ivo Montanhese, Rômulo Cândido de Souza e Orlando Reis. Aparecida: Editora Santuário; Petrópolis: Vozes, 1999.

HAGEN, Rose-Marie y Rainer. Los secretos de las obras de arte. Köln, Germany: Taschen GmbH, 2001.

LALANDE, André. Vocabulário técnico e crítico da filosofia. Trad. Fátima Sá Correia e outros. São Paulo: Martins Fontes, 1996

LICHT, Fred. Goya. Trad. Carmen González del Yerro. Madrid: Ediciones Encuentros S.

A., 2001.

WALTHER, Ingo F. Picasso. Trad. Ana Maria Cortes Kollert. Köln, Alemanha: Benedikt Taschen Verlag GMBH, 1994.

(1) Doutor em Educação, Mestre em Sociologia, Bacharel em Teologia e Licenciado em Filosofia.

(2) O motivo principal do nascimento de todas as grandes catacumbas, inclusive as de Santa Domitila, está ligado à sepultura de mártires. Eles foram vítimas das perseguições em particular dos imperadores Decio e Valeriano, nos anos 250 e 257 e da perseguição de Diocleciano em 303. As fotos acima estão no site: http://www.catacombe.domitilla.it/portoghese.htm

(3) Andrea Dué, Atlas histórico do cristianismo, 246.

(4) Francesco Goya, nasceu na Espanha, 1746- morreu na França, 1828.

(5) Nasceu em Málaga, Espanha, em 1881 e morreu em 1973, na França. 
(6) A guerra civil espanhola começou em julho de 1936 e terminou com a vitória dos revoltosos, Franco assumindo o poder em 1o de Abril de 1939, onde ficou até sua morte, em 20 de Novembro de 1975

(7) Fonte: História do Século XX, volume IV, Abril Cultural, in http://www.mundocultural.com.br/analise/guernica/panorama.html

(8) in Picasso, de Ingo F. Walther, p. 67

(9) in Picasso, de Ingo F. Walther, p. 70 